\title{
Analysis of the Competitiveness of Cuba and its Comparison with Selected Countries in Central America and the Caribbean
}

\author{
Petr Šmelc ${ }^{1}$ \\ 1University of Economics, Prague, Czech Republic
}

\begin{abstract}
The foreign sector of the Cuban economy was dominated by sugar exports until the early 1990s, but its volume fell sharply after the collapse of the Soviet Union and the associated loss of major consumer markets. Since then, Cuba has suffered from a chronic trade deficit, which has been around $10 \%$ of the country's GDP in recent years. The aim of this article is to assess the development of competitiveness of the Cuban economy and its comparison with selected countries within the region (Costa Rica, the Dominican Republic, and Nicaragua). The analysis of the selected indicators shows the low level of competitiveness and comparative advantages of Cuba when compared to all of the other countries covered in this review, but at the same time it shows the existence of revealed comparative advantages in the hi-tech industries, which also confirms the comparison of values of the so-called Balassa Index.
\end{abstract}

Keywords: Cuba; Competitiveness, Comparative Advantage, International Market, Balassa Index

\section{Introduction}

Cuba has been a relatively closed country, both politically and economically, with a predominantly centrally planned economy since the 1959 political coup up to today. Until 1990, the country was strongly supported economically by the Soviet Union. After its collapse and the ending of their mutual cooperation, there was an economic crisis in Cuba, which was only overcome with the help of Venezuela in the late 1990s. Cuba's cooperation with Venezuela began to lose its intensify after 2014, when falling global oil prices and the

\footnotetext{
${ }^{1}$ Disclaimer: The author of this article is an employee of the Czech National Bank. The views expressed in this article are those of the author and do not necessarily represent the views of the Czech National Bank.
} 
resulting income shortfall caused the Venezuelan economy to collapse. Naturally, both the Soviet Union and Venezuela contributed significantly to Cuba's foreign trade sector. This was dominated for most of the 20th century by sugar exports, which fell sharply, however, after the end of the cooperation with the Soviet Union and the loss of its most important markets. The country's inability to compensate for this loss is still evident from the low level of total amount of goods for export (below 3\% of GDP in 20172) and the country's chronic negative trade deficit (which reached 8\% in 2016). In recent years, Cuba has only managed to reduce this deficit by 'exporting' government employees (mainly doctors) to Venezuela, which is reported in the services side of the balance sheet and has thus significantly helped to keep the current balance of payments account positive.

This article aims to assess the development of the Cuban economy in terms of its competitiveness. Cuba is not included in the commonly used competitiveness indicators and is only rated by one of the major rating agencies (Moody's). A number of relevant indicators are also missing in the databases of the World Bank and other global institutions. In view of these limitations, the article selects competitiveness indicators whose values can be calculated using official data published in the official annual reports of the Cuban Statistical Office. The development of the figures of these indicators is then compared with a small number of selected countries from within the region, which were chosen due to their similarities with Cuba in terms of their population size and geographical conditions. The countries were also chosen so that the two politically most closed and two most open countries in the region were represented, while also taking into account the other conditions mentioned above.

\section{Literary Research}

For example, Čapek, Hájek and Mertlík (2002) define the competitiveness of a country as its ability to penetrate foreign and global markets with its tradable goods and services and to realize comparative advantages from such international exchange. In terms of measuring competitiveness, Kubišta (2009) divides the possible tools for its assessment into inputs (e.g. labor cost indicators, labor productivity, relative prices, real effective exchange rate), outputs (e.g. export performance indicators, relative strength of specialization, value added by processing) and so-called multidimensional factors (comprehensive indicators compiled for example by the World Economic Forum, the Institute for Management Development or the World Bank). Štěrbová (2013) uses the ranking ratings of reputable agencies among the competitiveness indicators (which places weigh on the degree of probability that a given entity will meet its debt obligations) or the country's involvement in international trade, which provides information on the importance of trade to the overall economy. However, she adds that the informational value of this approach has certain limits (as an example, she mentions developing

\footnotetext{
${ }^{2}$ Cuban Statistical Office (ONEI), Anuario Estadístico de Cuba 2018, Sector Externo, 2019.
} 
countries dependent on the exporting of one or a few commodities showing high indicator values, without this meaning that there is a high degree of competitiveness).

Regarding comparative advantage, which is a fundamental factor that affects the competitiveness of a given economy, the professional literature (Svatoš, 2009) defines it, for example, as a country's ability to produce goods and services at lower opportunity cost than its trading partners. Kubišta looks at the concept of "revealed comparative advantages" and the established assessments based on them, which follows the principle of economic theory that each country exports products for which it has better prospects than the partner country. As a way of assessing the country's comparative advantages, Kubišta recommends, in particular, an assessment of the commodity structure of exports, where the evident comparative advantages are evidenced by a higher share of manufactured products in the export of goods. To assess comparative advantages, the OECD has categorized the export industries according to their R\&D intensity, with IT companies, and the aerospace and pharmaceutical industries among the most demanding, high-tech sectors. Comparative advantages can be seen in the share of hi-tech products exported within the exports of manufactured finished products.

Another frequently used measure in empirical literature (e.g. Czarny and Żmuda, 2018; Abbas and Waheed, 2017; Shahab and Mahmood, 2013; Bender and Li, 2002; Sahinli, 2012; Batra and Khan, 2005) to assess the revealed comparative advantages is the socalled Balassa Index (or its further modifications), which assesses the proportion of export of the commodity / product / industry in total exports of the examined country (minus the surveyed item) in total global exports (minus the surveyed item). The revealed comparative advantage of the item under investigation exists when the value on the index is greater than 1 (Balassa, 1965).

As far as empirical literature is concerned, the issue of the competitiveness of the Cuban economy has been given very little attention to date, which is among other things related to the mentioned problem of missing or internationally incomparable data. One evaluation was carried out by Bonnett, Taylor and Messina (2001), by analyzing the development of the so-called relative export benefits (RXA) for the 10 most important agricultural and fishery products of Cuba during the period of 1985-1999. The calculation for RXA was derived from the Balassa calculation used to assess revealed comparative advantages. The analysis pointed in particular to a sharp decline in the export performance of the Cuban sugar industry after 1990 and some reallocation of resources towards, in particular, citrus processing or the tobacco industry. However, this work did not deal with the comparison of Cuba with other countries.

There are several studies focused on evaluating competitiveness of countries in Latin America and the Caribbean, but mostly they exclude Cuba from the comparison. Worell, Greenidge and Lowe (2013) measured the impact of price competitiveness on the growth of tradable output in the Caribbean and Central America by comparing the impact of both price and non-price factors. The price competitiveness measures included real effective exchange rates and price competitiveness index. The concept of revealed comparative 
advantage was used among the non-price measures and showed that although most countries in the sample improved between 1980 and 2010 the competitiveness in services (this was the case also for Costa Rica, Dominican Republic and Nicaragua), the competitiveness in goods was maintained or suffered losses. The main finding of the study is that the main factor in the growth of tradable output in the Caribbean and Central America was the growth of world demand for the region's exports, the impact of price competitiveness proved to be insignificant. Mortimore and Peres (2001) analyzed the evolution of international competitiveness in the countries of Latin America and Caribbean in the 1990s. The study assessed the competitiveness of different groups of countries through the comparison of technological specialization using the technological specialization indices (TSIs), which are calculated as the ratio between the market share of a country (or group of countries) in high- and medium-technology sectors and its share in low-technology sectors. Although the TSI of the region doubled between 1985 and 1998, it was still lower than the values achieved by other countries in the comparison (comparison comprised Latin American and East and South-East Asian countries). The study also compares changes in world market shares among Latin American countries between 1985 and 1998. Out of 25 countries, Cuba was on $14^{\text {th }}$ place with change of its world market share between 1985 and 1998 of $-0.01 \%$.

\section{Methods and Data}

The assessment of Cuba's competitiveness is significantly hampered by the lack of availability of a number of sets of data on the Cuban economy and simultaneously by the country not being included in any of the major multidimensional competitiveness indicators (i.e. Cuba is not included in the Global Competitiveness Index, the Ease of Doing Business Index or the World Competitiveness Scoreboard). As far as it its rating by rating agencies, it is assessed only by Moody's and its current (2019) rating is Caa2.

Given the availability of data on Cuba, the indicators (1) of the country's involvement in international trade have been chosen from the possible ways of assessing competitiveness and comparative advantages mentioned in theoretical literature; as well as (2) the proportion of exported manufactured finished products within the total amount of exported goods; and (3) the proportion of exports from the hi-tech sectors in terms of manufactured finished products; and (4) the Balassa index of revealed comparative advantages within hi-tech sectors.

The figures of the selected indicators can be found in the World Bank Open Data for most countries. However, in many cases Cuba is either not included among the countries under review, or the data for this country are incomplete. As a result, the figures of the indicators for Cuba are then calculated from the annual reports of the Cuban Statistical Office (Oficina Nacional de Estadísticas de Cuba - ONEI), in which the figures relate to the volumes of individual items of Cuban foreign trade that are itemized according to SITC standards. 
This paper will focus on the assessment of exports of goods (excluding the export of services) for the countries under review due to the confusing reporting concerning the exports of services by Cuba, which is mainly comprised of Cuba's state employees working in Venezuela in the context of the political cooperation between the two countries (there is more information about this cooperation below). Taking into account the export of services would make it impossible to assess Cuba's competitiveness and for comparing it with the selected countries.

The development of the figures of the individual indicators will then be compared with the selected countries from Central America and the Caribbean. The four chosen countries represent a group of countries with similar geographic conditions and population sizes, and also represent the two most politically closed and two most open countries. (It should be noted that The Democracy Index prepared by the Economist Intelligence Unit was used for this evaluation). Nicaragua (Democracy Index in 2019 - 3.55), Costa Rica (8.13) and the Dominican Republic (6.54) were selected in this way. Cuba has a Democracy Index of 2.84 .

\section{The Cuban Economy, the development of the foreign trade sector including a comparison with the countries under review}

Since the revolution in 1959 , Cuba has been a country with a predominantly centrally planned economy, and according to the classification of the UN it remains a developing country (2019). Although its GDP per capita (at current rates) was $\$ 8,617$ USD $^{3}$ in 2017 , some analysts (for example Alejandro, 2020) dispute this figure and estimate its real value to be around a third. Due to the fact that Cuba is not a member of the World Bank or the International Monetary Fund, this figure is impossible to verify.

Since the revolution in 1959, the more economically successful periods in Cuba have always been associated with significant, politically motivated support from foreign partners - first from the Soviet Union (1962-1990) and later from Venezuela (2000-2016). During time periods when Cuba lacked a strong foreign supporter, especially during the 1990s, its economy has been in a state of deep crisis. These developments point to the considerable failure of the Cuban economic model, which, without foreign support, is unable to achieve economic success, in particular, in the form of sustainable growth and raising living standards. The poor performance of the Cuban economy has also been demonstrated by the state of its foreign trade sector, where the amount of imported goods has exceeded its exports (by a factor of four in 20174) and the foreign trade deficit stood at 8\% of GDP5 (2016). Cuba managed to maintain its current account balance only in positive terms thanks to a significantly surplus in its balance of services (11\% of GDP in $2015^{6}$ ), which was largely due to the exporting of Cuban civil

\footnotetext{
3 ONEI: Anuario Estadístico de Cuba 2018, Cuentas nacionales, 2019.

4 ONEI, Anuario Estadístico de Cuba 2018, Sector Externo, 2019.

5 Ibid.

${ }^{6}$ Ibid.
} 
servants to Venezuela (the main part of which is reported in the services balance) ${ }^{7}$. Analysts (for example Mesa-Lago, 2019) have cited the complicated system of the country's two currencies (the Cuban peso and the convertible peso or CUC) as one of the fundamental limits of Cuban exports, whose non-transparent currency conversion favors imports over exports. Also, the non-convertible nature of the currencies and their fixed exchange rates do not allow them to be adapted to the size of demand for Cuban goods (using a so-called exchange-rate balancing mechanism).

Regarding the structure of Cuban goods for export, it is only represented by a narrow group of commodities. In 2017, Cuba's main export products were sugar (19\% of Cuban exported goods), nickel (18\%) and pharmaceuticals (13\%). The main export destinations were Canada (19\% of Cuban exported goods), Venezuela (16\%) and China (15\%). The total value of these exported goods was $\$ 2.3$ billion USD ${ }^{8}$.

Looking at the performance of the economies under comparison since 1960, as measured by GDP per capita in constant USD (see Figure 1), a similar starting point (between $\$ 1,300$ USD and $\$ 2,900$ USD) can be seen for all four countries and then followed by the widening of their differences. Cuba experienced considerable growth during the first half of the 1980s (in 1985 its GDP per capita was even higher than that of Costa Rica), but after 1990 and the end of its cooperation with the Soviet Union, Cuba experienced a profound slump, with its GDP falling by more than 30\% between 1991 and $1993^{\circ}$. At present, the GDP per capita in Cuba is similar to that of the Dominican Republic with an interval of $\$ 2,000$ $\$ 3,000$ USD less than Costa Rica. Since the 1980s, Nicaragua has consistently been at the lowest level of these four countries with a per capita GDP that has been below $\$ 2,000$ USD for a long time.

Figure 1: Per Capita GDP (in constant USD)

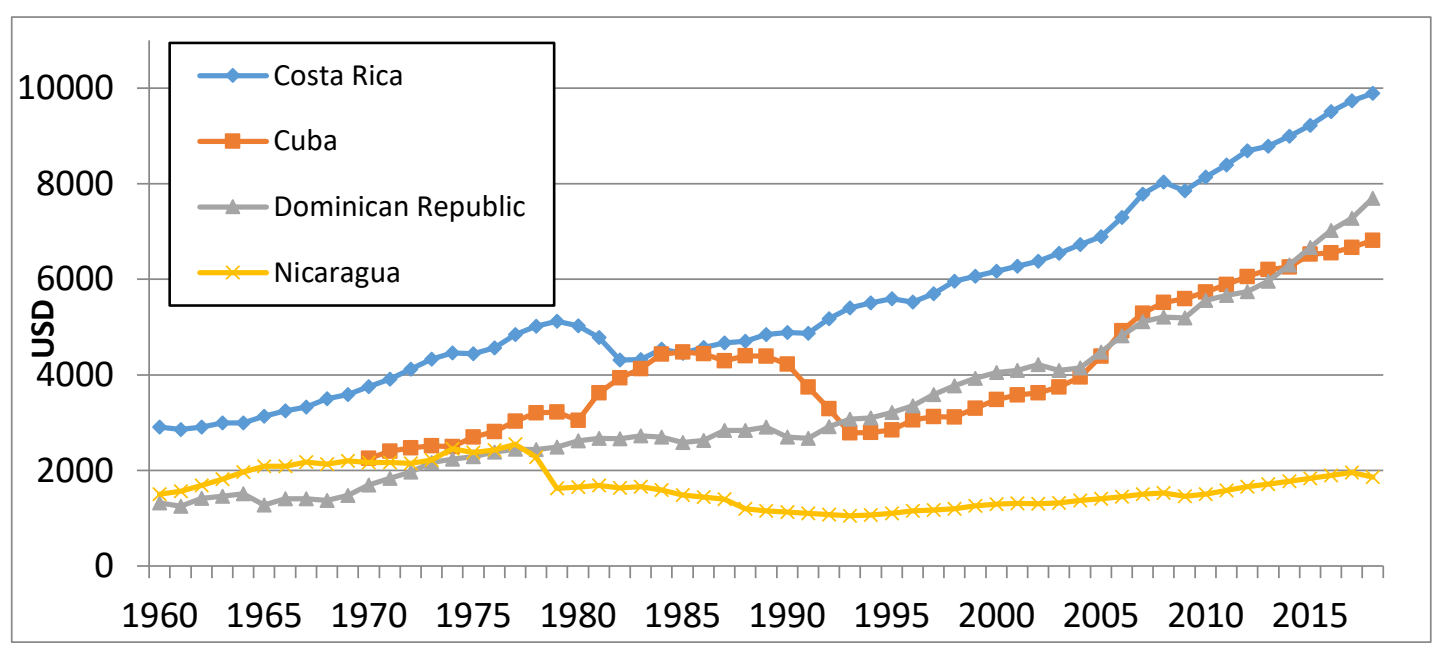

Source: The World Bank, arranged by the author.

\footnotetext{
7 More on this topic for example in Hernández-Catá, E.: Cuba's swaps of petroleum for doctors and the impact of cutbacks in Venezuelan oil deliveries, 2019.

${ }^{8}$ ONEI, Anuario Estadístico de Cuba 2018, Sector Externo, 2019.

${ }^{9}$ World Bank.
} 
With the analysis carried out above in mind, it is also worthwhile to compare the development of the percentage of exported goods of these selected countries in terms of the global export economy. Although this comparison has a number of limitations (e.g. it does not take into account the different populations of selected countries), it offers an interesting insight into the evolution of the importance of global trade for these specific countries. The comparison graphed in Figure 2 shows that Cuba's share of global trade was several times higher than in the other included countries before 1990, as well as the country's subsequent sharp decline. Since 2014, Cuba's percentage has been the lowest out of the four countries. Historically speaking, the high levels were related to Cuba's strong orientation towards sugar exports during its cooperation within the Council of Mutual Economic Assistance (COMECON).

Figure 2: Percentage of Exported Goods from the Selected Counties in the Global Export Economy

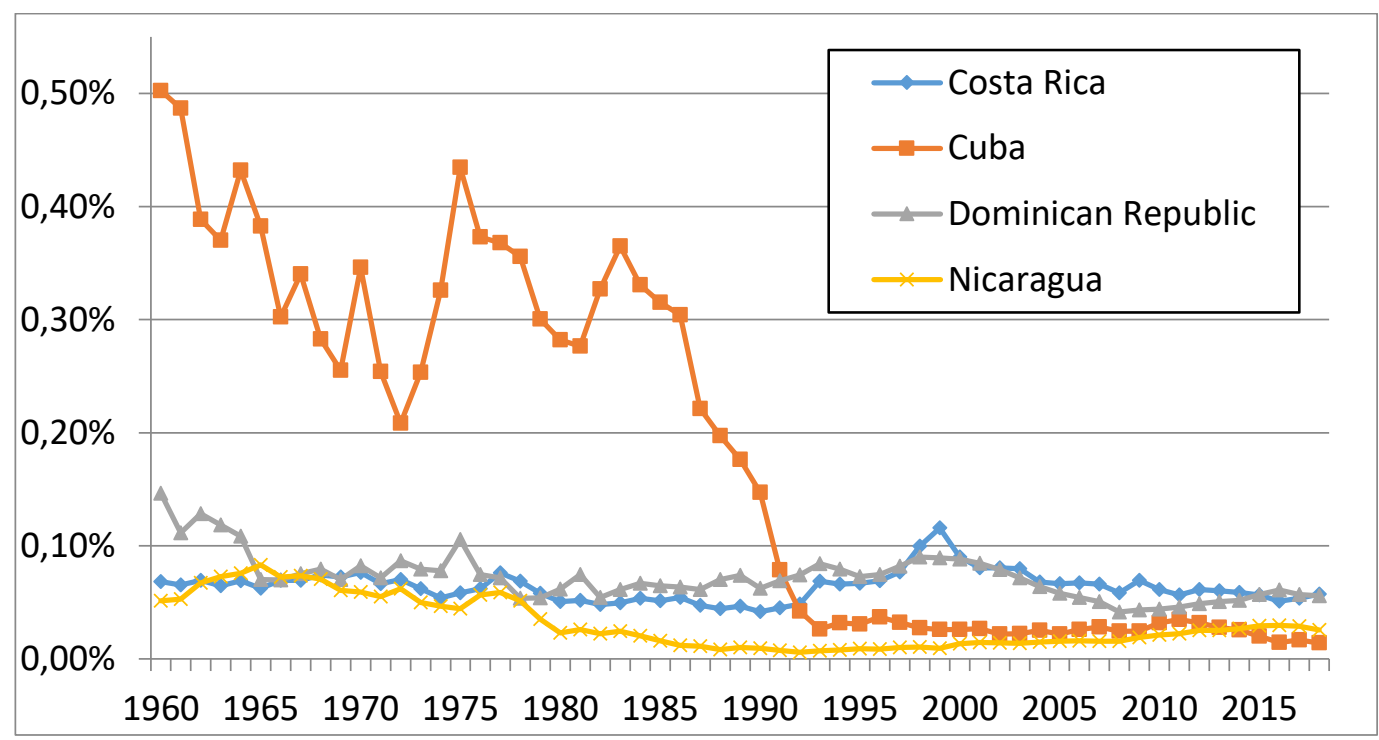

Source: The World Bank, arranged by the author.

\section{Results}

In this section, the results of the comparison of Cuba's competitiveness with the three selected countries from the region will be presented using the above-described indicators offered by theoretical literature.

\section{Degree of involvement in international trade}

The degree of country's involvement in international trade (often referred to also as the degree of openness of an economy) is usually assessed on the basis of its share of exports in relation to its GDP (sometimes also the share of imports or the sum of exports and imports). As far as Cuba is concerned, the country has gone through several fundamental changes since the 1960s in terms of its share of exports (in this analysis we consider only the export of goods, see above) in relation to its GDP. In Figure 3, we can see an increase 
in this proportion and that it maintained shares between $25-30 \%$ during the 1970 s and 1980s. However, after 1990 this was followed by a sharp decline to figures that have been below $5 \%$ since 2015 .

As previously outlined above, the significantly higher importance of exports to the Cuban economy was due to its strong focus on the production of sugar and sugar exports, which lasted until the early 1990s. Sugar exports were already dominant in the Cuban economy prior to the Cuban Revolution of 1959, when the Cuban sugar industry was closely connected to the US, where most of the sugar exports went. Following the political reorientation of Cuba and the related imposition of a US trade embargo in the early 1960s, Cuba entered into close cooperation with the Soviet Union and the Eastern Bloc countries, which was institutionalized by Cuba's accession to the Council of Mutual Economic Assistance (COMECON) in 1972. Within the framework of their role as the main supplier of sugar, Cuba was allowed to export sugar at prices several times higher than the going market rates (Pérez-López, 2016). One consequence of this support was the abandonment of Fidel Castro's initially proclaimed goal of the diversification of agriculture and the industrialization of the economy. On the contrary, this led to an intensification of Cuba's orientation towards the sugar industry (Politt, 2004). For instance, the percentage of sugar in the country's total exports was around 75\% during the second half of the 1980s (Pérez-López, 2016). After the collapse of the Soviet Union and the end of mutual cooperation, Cuba lost the majority of its export markets, which it failed to replace. Production was also declining due to missing inputs (e.g. spare parts for agricultural machinery, fertilizers or pesticides), which had been largely provided by the Soviet Union until then. In the most current available figures, the share of sugar in the total exports of goods was $19 \%(2017)^{10}$. Cuba has been unable to compensate for the loss of sugar exports by any other product, and its share of exported goods to GDP fell from an average of $25 \%$ from the 1980 s to around $3 \%(2017)^{11}$.

In particular, the long-term inability to substitute sugar exports for exports of another commodity or another product has led Cuba to lag behind in this indicator in comparison with the selected countries in the region (see Figure 3). Since 1990, Cuba has been the most closed economy out of these counties. In 2018 (the last set of figures available) the value of the indicator for Cuba was 3\%. Nicaragua (38\%) was the highest this year, followed by Costa Rica (19\%) and the Dominican Republic (13\%).

\footnotetext{
10 ONEI, Anuario Estadístico de Cuba 2018, Agricultura, ganadería, silvicultura y pesca, 2019.

11 ONEI, Anuario Estadístico de Cuba 2018, Sector Externo, 2019.
} 
Figure 3: Percentage of Exported Goods in relation to GDP

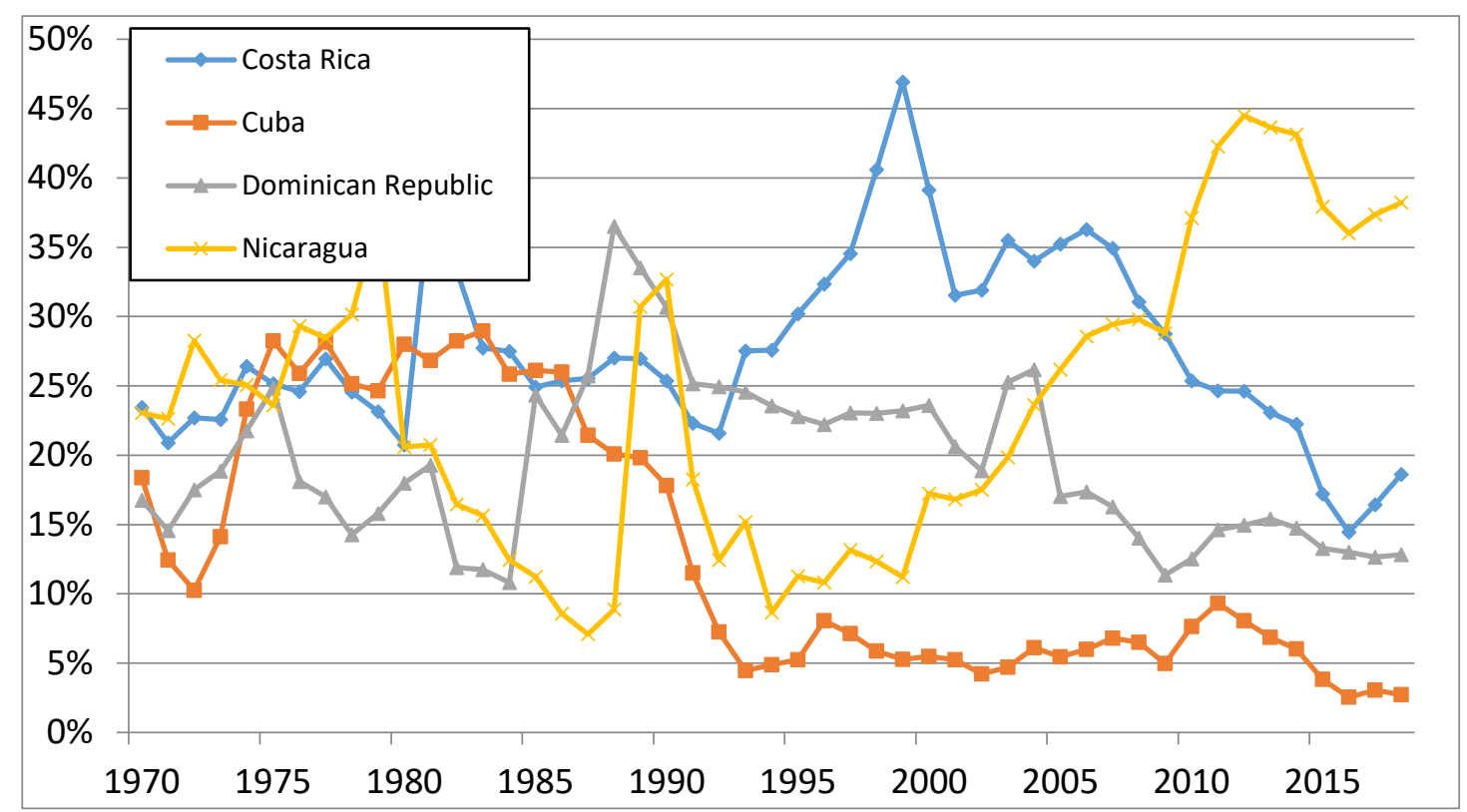

Source: The World Bank, arranged by the author.

\section{The percentage of manufactured finished products within exported goods}

The indicator of the percentage of manufactured finished products within exported goods, takes into account the commodity structure of the country's exports and points out the degree of its revealed comparative advantages, while also providing a greater indication of the country's competitiveness. Evident comparative advantages are shown by a higher proportion of manufactured finished products. For developed countries, this proportion usually exceeds 80\% (Kubišta et al., 2009).

The World Bank database contains the values of the monitored indicator for Cuba only for the period between 1998 and 2006, the data for the later period were calculated from data in the Cuban Statistical Office's Annual Reports. As can be seen in Figure 4, the share of manufactured finished products in Cuba grew from 11\% in 1998 to the current rate of $28 \%$ (2018). This share reached its highest percentage in 2009, when it was $30.9 \%$. However, the higher figures of this indicator (especially in 2005, 2009, 2016 and 2018, when they ranged between 25-31\%) were mainly due to a decline in the total of exported goods. Regarding Cuba's manufactured export composition (as shown in Figure 5) by far its most important category is Category 5 of the International Standard Classification of Goods, Revision 4 (SITC) - 'Chemicals and related products not mentioned anywhere else', whose share in the manufactured finished products increased from $28 \%$ in in 2000 to $80 \%$ in 2016, when its value reached \$494 million USD. In 2017 and 2018, the share of Category 5 goods fell to $75 \%$ and $69 \%$, respectively, however, the data for the last two years are incomplete in the current annual reports from Cuba's Statistical Office and may be corrected. The actual value of the Category 5 goods is comprised mainly of goods that fall under subheading 54 (pharmaceutical products), which in 2016 (the latest available figures) accounted for $90 \%$ (and $72 \%$ of the total exports of manufactured finished goods). 
The figures of this monitored indicator are thus mainly made up of the exports of pharmaceuticals. This makes sense given Cuba's long-term focus on the pharmaceutical sector and how strongly it is connected to the Cuban health system, which had to be reoriented and become more self-sufficient as a result of the US trade embargo. In the 1980s, a number of Cubans were sent to study academic fields related to biotechnology in the Soviet Union and Eastern European countries. These fields remained a priority even during the crisis of the 1990s when Cubans studied at universities and worked in research institutes in countries such as Sweden, Germany or Spain. Between 1990 and 1996, the Cuban government invested $\$ 7$ billion USD in the development of biotechnology centers around Havana. These centers currently employ more than 7,000 Cuban scientists and technicians and are the heart of Cuba's drug research and production facilities. The Cuban biotechnology complex produces a wide range of products such as vaccines, diagnostic systems, enzymes, products for molecular biology, monoclonal antibodies, among others (Spadoni, 2014). Although in terms of R\&D expenditures as a percentage of the GDP, Cuba invests more than most of the other countries in the region, compared with the rest of the world the amounts of investment are not exceptional (Cárdenas, 2009).

Regarding the export of pharmaceuticals, the government has established a number of partnerships, both with developing and developed countries, with the goal of furthering the development of the research, production, commercialization and international recognition of Cuban products. However, due to the complicated approval process, most of these exports still go to developing countries. (Cárdenas, 2009). For example, in 2017, the main importers of packaged medicines were Belarus $16 \%$ (of packaged medicines for export), Algeria 17\%, Ecuador 13\%, as well as the Czech Republic with $8 \%{ }^{12}$ (according to the Czech Statistical Office the total value of imported medicine from Cuba was $\$ 657,000$ USD last year). Part of this production was also exported to Venezuela as a result of the mutual cooperation between the two countries, which led to a significant increase in pharmaceutical exports after 2003. Due to the gradual reduction of the mutual cooperation after 2014, we can expect a decline in pharmaceutical exports, which is a highly likely explanation for the decrease in total pharmaceutical exports since 2015, when the volume of exported medicines decreased by $27 \%$ year-on-year. However, given the decline in total exports of goods, this decline had no significant impact on the indicator being discussed.

Despite the well-developed pharmaceutical industry, Cuba lags behind all of the countries under review in terms of the indicator of the percentage of manufactured finished products within exported goods. Its current figure of $28 \%$ is also very different from that of developed countries. The best results are compared to those of the Dominican Republic and Costa Rica, which (last year is 2017) reached 69\% and 53\% respectively, while the figure for Nicaragua was $45.8 \%$.

12 Observatory of Economic Complexity 
Figure 4: Percentage of Manufactured Finished Products within Exported Goods

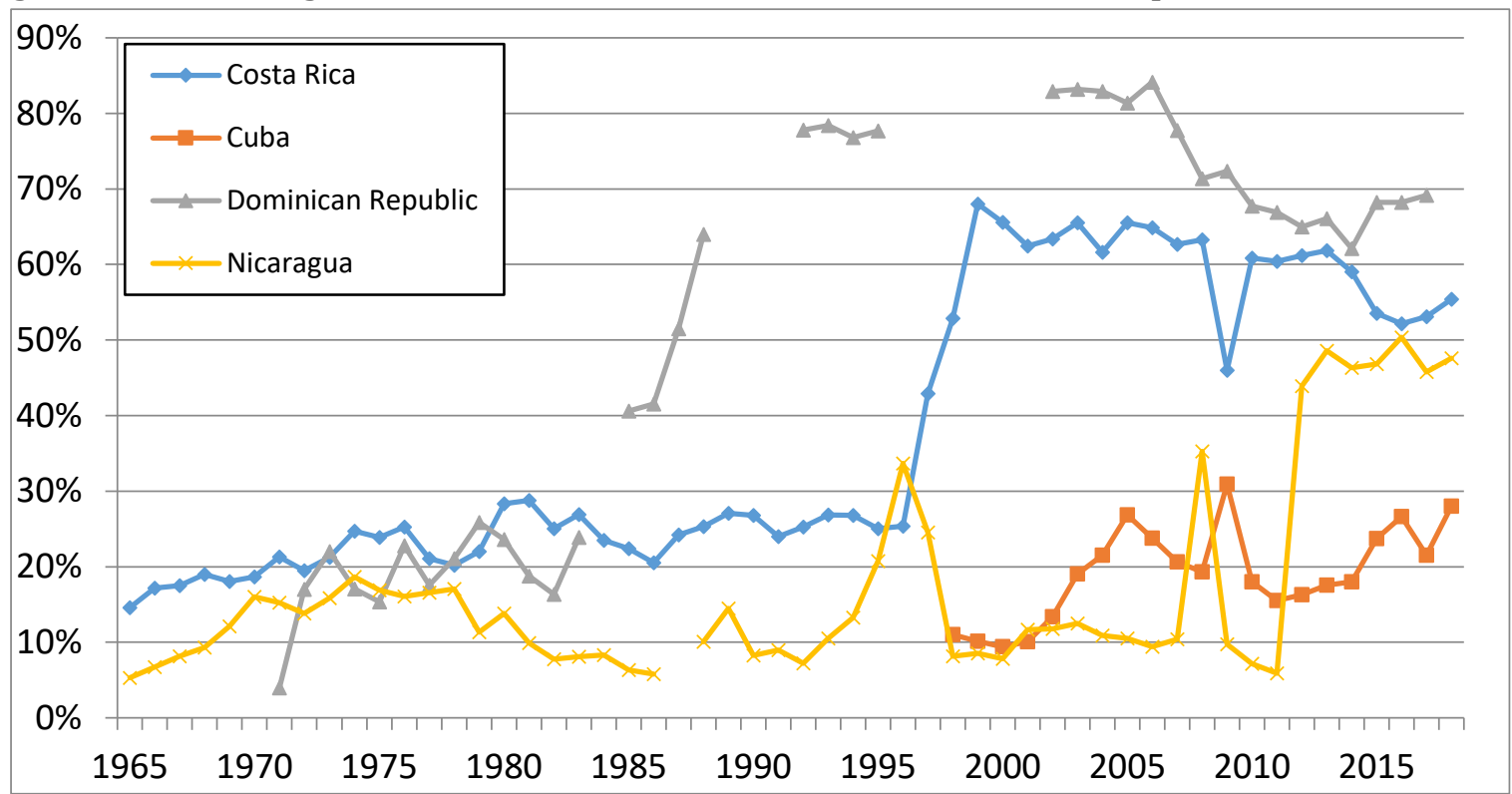

Source: The World Bank and the Cuban Statistical Office, arranged by the author.

Figure 5: Exports of manufactured finished products including individual categories

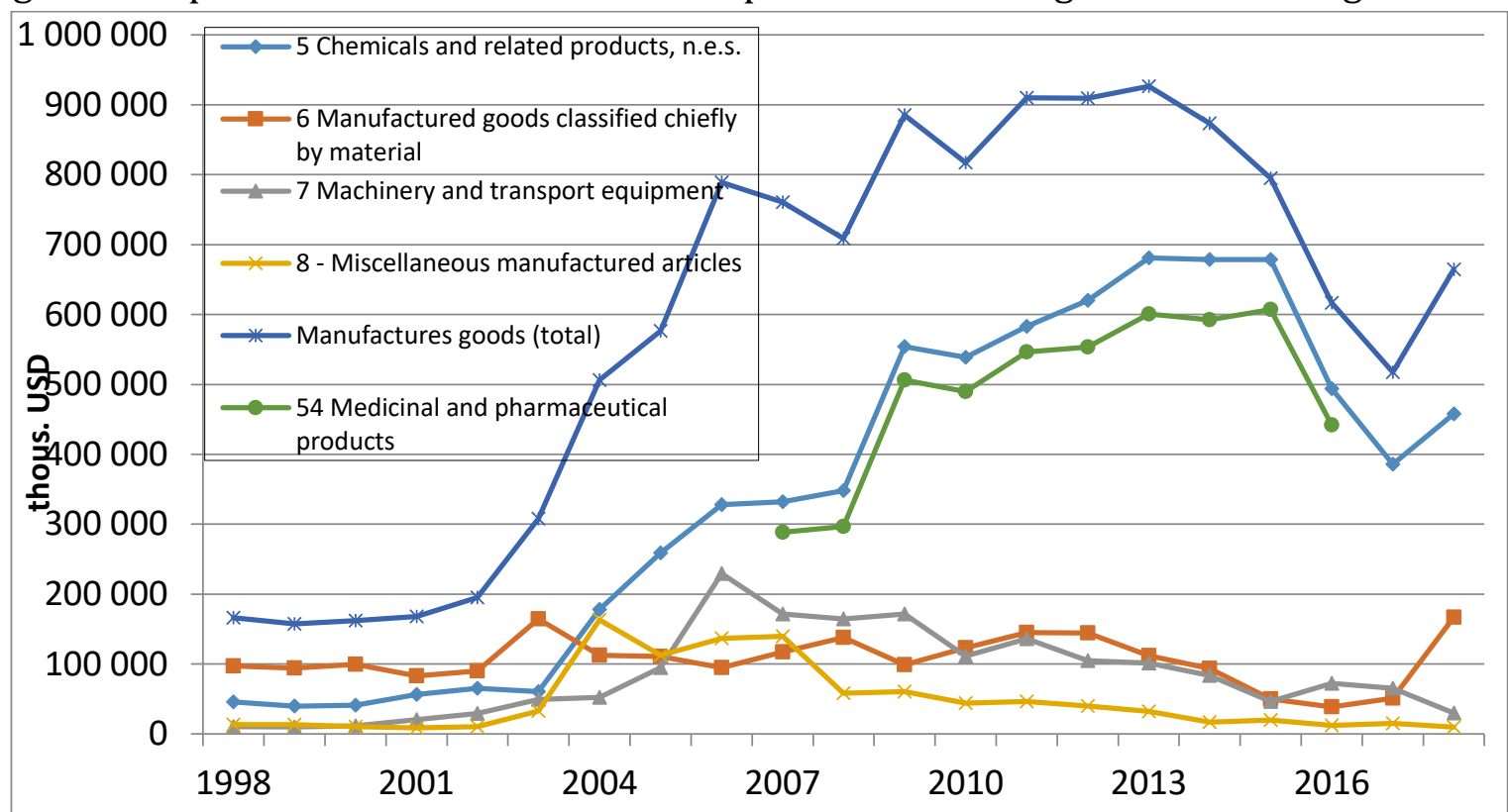

Source: The World Bank and the Cuban Statistical Office, arranged by the author.

\section{The percentage of hi-tech products within exported manufactured finished goods}

Another indicator used to assess the amount of comparative advantages and the degree of competitiveness of the examined economies is the indicator of the proportion of exported hi-tech products within exported manufactured finished products. The figures for this indicator are available for most countries in the World Bank database. However, this database does not contain data for Cuba, which has therefore been calculated from the data available in the Cuban Statistical Office's Annual Reports. According to the Classification of Economic Activities of Revision 2 (NACE Rev. 2), the high-tech industries 
include products classified under Division 21 (the manufacture of basic pharmaceutical products and pharmaceutical preparations), Division 26 (the manufacture of computers, electronic and optical equipment) and the group of goods that fall under Division 30.3 (the manufacture of aircraft and their engines, spacecraft and related equipment). According to the Cuban Statistical Office's Annual Reports the Cuban exported goods are reported in accordance with Chapters 54, 75, 76, 87 and 88 as classified within the SITC system.

The development of this indicator for Cuba and the countries under review is shown in Figure \#6. The value of the monitored indicator for Cuba between 2007 and 2016 (data is available only for this period) increased from $52.4 \%$ to $77.8 \%$ in 2015 . In 2016 it fell to $73 \%$. The high figures are explained by the dominance of the pharmaceutical industry within the manufactured finished products sector, which is classified as a hi-tech sector and whose export position has been described in the previous section.

Cuba's unambiguous lead and separation from the researched countries in terms of this indicator, which increased even more between 2007-2017 (though a certain drop can be seen in the latest data between 2015 and 2016), can be seen by looking at Figure \#6. In 2017 the figure for the indicator was $18.5 \%$ for Costa Rica, $8.6 \%$ for the Dominican Republic and $0.6 \%$ for Nicaragua.

Figure 6: Percentage of hi-tech products in the export of manufactured finished goods

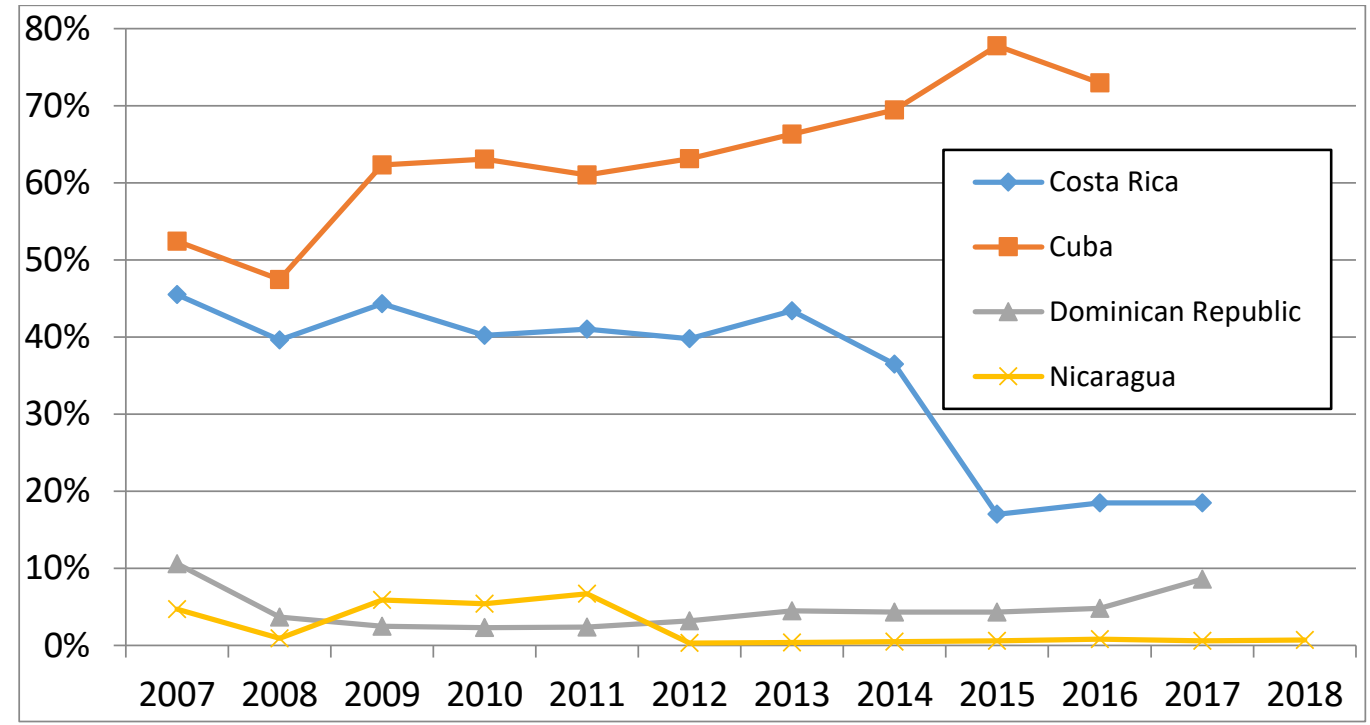

Source: The World Bank and the Cuban Statistical Office, arranged by the author.

\section{Index of revealed comparative advantages (RCA) in hi-tech industries}

The last indicator examined here is the Balassa Index of Revealed Comparative Advantages (RCA) in terms of the hi-tech sector. This indicator broadens the assessment made in section 3 (the percentage of exported hi-tech products within exported manufactured finished goods), by comparing the existence of a comparative advantage in a global context through the RCA index. The period under review in this case is from 2013 
to 2016, for which the figures for exported hi-tech manufactured goods are measurable in the database of the World Bank.

As can be seen from Figure 7, revealed comparative advantage has been shown, according to this index for high-tech industries only in Costa Rica in 2013 and 2014, and for Cuba in 2015 and 2016, which is the only country out of these four that has a clear comparative advantage for hi-tech industries since 2015. In 2016, the index value for Cuba was 1.49, for Costa Rica 0.8, for the Dominican Republic 0.15 and for Nicaragua 0.02 .

Figure 7: Revealed Comparative Advantage Index (RCA) for exported high-tech products

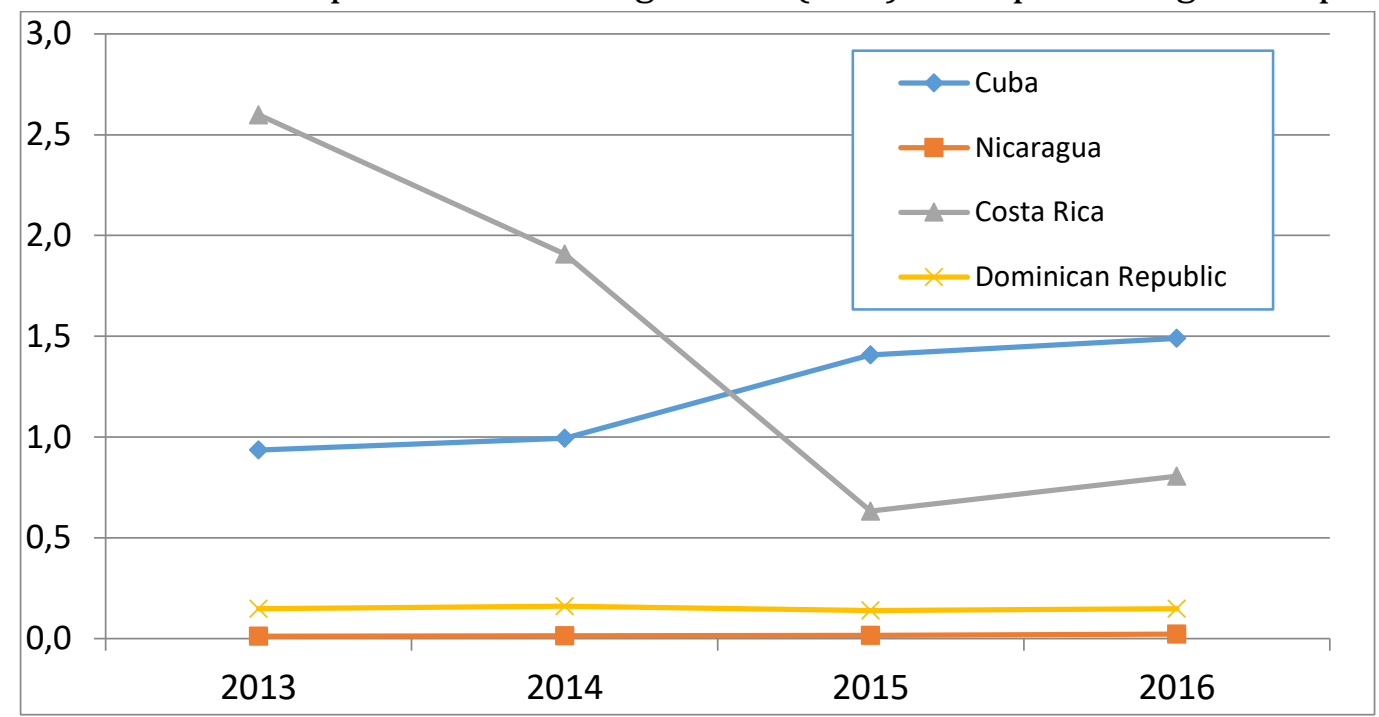

Source: The World Bank and the Cuban Statistical Office, arranged by the author.

\section{Discussion}

The aim of this article was to evaluate the competitiveness of Cuba and to see how this measure was in comparison with the selected countries from Central America and the Caribbean. There was a significant reduction in Cuba's involvement in international trade after the end of its cooperation with the Soviet Union in the early 1990s and has led to it lagging behind the countries under review over the long term. Another finding was the very low share of exported manufactured finished products within its total exports, which is also at the lowest level in comparison with the countries under review. This finding points to a low level of the revealed comparative advantages of Cuban exports over the countries chosen within the region. In general, these comparisons point to Cuba's low level of competitiveness within the region and low comparative advantages when compared to both more politically open countries (Costa Rica, Dominican Republic) and more closed countries (Nicaragua). Thus, the poor development and ongoing isolation of Cuba's merchandise trade proved to be rather exceptional in the regional context.

The comparison between the development of high-tech products for export to the overall amount of the manufactured finished goods for export, which has reached shares close to $80 \%$ in recent years and was consistently the highest rate among the countries under review, points to a more positive finding for Cuba. The Balassa RCA Index showed a clear 
comparative advantage in the hi-tech sector, with Cuba achieving the highest figures among the countries under review in 2015 and 2016 (the two most recent years with available data). An analysis of the composition of these exports has shown that the value of hi-tech exports is predominantly made up of exported pharmaceutical products, in whose production the Cuban government invested heavily during the 1980s and 1990s.

The findings of this analysis are generally in line with the findings of other studies that show significant decline in Cuban sugar industry and reallocation of resources towards other industries (Bonnett, Taylor and Messina, 2001), and also major decline (highest among selected countries) of Cuba's export market share at the beginning of the 1990s (Mortimore and Peres, 2001). The analysis further extends these results by making a comparison with other countries within the region.

The findings regarding the existence of Cuba's comparative advantages in the hi-tech sector further complement the analysis of Cuba's biotechnology industry by Spadoni (2014) and Cárdenes (2009). Nevertheless, there is a lack of more detailed, especially up to date, analysis of this issue, which would be important to conduct in context of Cuba's potential development and also possible future shift towards more market-oriented economy. Questions for further assessment include for example Cuba's possibilities to attract foreign direct investment in the biotechnology sector, possibilities to compete with major pharmaceutical companies in developed countries and increase of its market share or Cuba's possibilities to sustain or increase its R\&D expenditures.

\section{Conclusion}

The conclusion of this analysis is the finding that Cuba has a low competitiveness in comparison with all of selected countries from the region. However, at the same time the existence of comparative advantages has been demonstrated in the hi-tech sector, especially within the pharmaceutical industry, where Cuba is achieving significantly better results than the other countries in the region. This result points to some of the island's potential in terms of the allocation of Cuba's resources, especially when it comes to manufactured finished goods, which could be further addressed, for example, in the context of analyzing opportunities for foreign investors, or in regard to the potential transformation of the Cuban economy into a market based economy.

\section{References}

1. ABBAS, S., W. ABDUL, 2017. Trade competitiveness of Pakistan: evidence from the revealed comparative advantage approach. Competitiveness Review. 27(5).

2. ALEJANDRO, P. V., 2020. Where the Cuban Economy Stands in Latin America: A New Measurement of Gross Domestic Product. Cuban Studies. 49.

3. BALASSA, B., 1965. Trade Liberalization and Revealed Comparative Advantage. Manchester School of Economic and Social Studies. 33. 
4. BATRA, A., Z. KHAN, 2005. Revealed Comparative Advantage: An Analysis for India and China. Working Paper No. 168, Indian Council for Research on International Economic Relations (ICRIER).

5. BENDER, S., L. KUI-WAI, 2002. The Changing Trade and Revealed Comparative Advantages of Asian and Latin American Manufacture Exports. Working Papers 843, Economic Growth Center, Yale University.

6. BONNETT, E. T., T. G. TAYLOR, W. A. MESSINA, 2001. Cuba: A View of Revealed Export Advantage. Association for the Study of Cuban Economy [online]. [accessed: 2019-12-15], available from: <https://www.ascecuba.org/asce_proceedings/cuba-a-view-of-revealed-exportadvantage/>.

7. CZARNY, E., M. ŻMUDA, 2018. Competitiveness as the Ability to Adjust: the EU-10 Exports. Comparative Economic Research. 21(1).

8. Czech Statistical Office [online]. [accessed: 2020-01-05], available from: https://www.czso.cz/csu/czso/home.

9. CÁRDENAS, A., 2009. The Cuban Biotechnology Industry: Innovation and universal health care. Institute for Institutional and Innovations Economics. University of Bremen, Germany.

10. ČAPEK, A., M. HÁJEK, P. MERTLÍK, 2002. Konkurenceschopnost české ekonomiky [Competitiveness of Czech economy]. Prague. University of Economics.

11. Economist Inteligence Unit: Democracy Index 2019 [online]. [accessed: 13. 2. 2020], available from: <https://www.eiu.com/topic/democracy-index>.

12. HERNÁNDEZ-CATÁ, E., 2019. Cuba's swaps of petroleum for doctors and the impact of cutbacks in Venezuelan oil deliveries. Association for the Study of Cuban Economy [online]. [accessed: 2020-02-01], available from: <https://www.ascecuba.org/c/wp-content/uploads/2020/01/v29asce_2019_05hernandezcata.pdf>.

13. KUBIŠTA, V. et al., 2009. Mezinárodní ekonomické vztahy [International economic relations]. Prague. Aleš Čeňek.

14. MESA-LAGO, C., 2019. The Cuban Economy after six decades of socialism: changes, continuities and worsening crisis. Association for the Study of Cuban Economy [online]. [accessed: 2020-02-02], available from: <https://www.ascecuba.org/c/wp-content/uploads/2020/01/v29asce_2019_04mesolago.pdf>.

15. MORTIMORE, M., W. PERES, 2001. Corporate competitiveness in Latin America and the Caribbean. CEPAL Review. 74(8), 35-57.

16. OECD.Stat: High, medium and low technology exports [online]. [accessed: 202001-15], available from: $<$ https://stats.oecd.org/oecdstat_metadata/ShowMetadata.ashx?Dataset=CSP6\& Coords=\%5BSUB\%5D.\%5BHTEXPORT\%5D\&Lang=en $>$.

17. Oficina nacional de Estadística e Información, Anuario Estadístico de Cuba 2018, Agricultura, ganadería, silvicultura y pesca, 2019. 
18. Oficina nacional de Estadística e Información, Anuario Estadístico de Cuba 2018, Cuentas nacionales, 2019.

19. Oficina nacional de Estadística e Información, Anuario Estadístico de Cuba 2018, Sector Externo, 2019.

20. Observatory of Economic Complexity [online]. [accessed: 2020-01-17], available from: <https://oec.world/en/>.

21. PÉREZ-LÓPEZ, J., 2016. The Restructuring of the Cuban Sugar Agroindustry: A Progress Report. Association for the Study of Cuban Economy [online]. [accessed: 2020-01-15], available from: <https://www.ascecuba.org/asce_proceedings/therestructuring-of-the-cuban-sugar-agroindustry-a-progress-report/>.

22. POLLITT, H. B., 2004. The Rise and Fall of the Cuban Sugar Economy. Journal of Latin American Studies. 36, 319-348.

23. SAHINLI, M. A., 2013. Comparative advantage of agriculture sector between Turkey and European Union. African Journal of Agricultural Research. 8(10), 884895.

24. SVATOŠ, M. et al., 2009. Zahraniční obchod, teorie a praxe [Foreign trade, theory and practice]. Prague. Grada Publishing.

25. SPADONI, P., 2014. Cuba's Socialist Economy Today: navigating challenges and change. Colorado. Lynne Rienner Publishers.

26. ŠTĚRBOVÁ, L. et al., 2013. Mezinárodní obchod ve světové krizi 21. století [International trade in the world crisis of $21^{\text {st }}$ century]. Prague. Grada Publishing.

27. TORRES, N. G., 2018. Cuba is a lot poorer than the government reports, a new study shows. Miami Herald [online]. [accessed: 2020-01-15], available from: $<$ http://www.miamiherald.com/news/nationworld/world/americas/cuba/article195681589.html>.

28. United Nations: World Economic Situation, Prospects [online]. [accessed: 2020-0219], available from: <https://www.un.org/development/desa/dpad/wpcontent/uploads/sites/45/WESP2019_BOOK-ANNEX-en.pdf>.

29. World Bank Open Data [online]. [accessed: 2020-02-01], available from: <https://data.worldbank.org/l>.

30. WORRELL, D., K. GREENIDGE, S. LOWE, 2013. Competitiveness in the Caribbean and Central America. International Research Journal of Finance and Economics. 109.

\section{Contact address of the author:}

Ing. Petr Šmelc, University of Economics, Prague, Faculty of International Relations, Department of International Business, e-mail: petr.smelc@cnb.cz 